Letter to the Editor

\title{
Outcomes of Surgically Treated Fingertip Injuries in Migrant Workers
}

\section{Dear Editor,}

Singapore employs more than 284,900 migrant construction workers. ${ }^{1}$ Although safety training has been mandated to reduce the likelihood of workplace injuries, more than 12,000 workplace injuries have been reported in migrant construction workers in the latest statutory report. ${ }^{2}$ We conducted a retrospective review of prospectively collected outcomes of surgically treated fingertip injuries in migrant workers at our tertiary teaching hospital between January 2015 to December 2015. Patients were included if they were (i) migrant construction workers, (ii) sustained a fingertip injury, (iii) underwent surgical treatment and, (iv) completed a minimum of 6 months follow-up. Participants were excluded if they had polytrauma or a concomitant fracture proximal to the fingertip. The study was approved by the SingHealth Institutional Review Board (CIRB 2016/2938).

Outcome measures included the total active motion (TAM), defined as the sum of active metacarpophalangeal (MCP), proximal interphalangeal (PIP) and distal interphalangeal (DIP) arc of motion of an individual digit. ${ }^{3}$ Outcomes were categorised as per the American Society for Surgery of the Hand (ASSH) into excellent (100\%), good $(>75 \%)$, fair $(>50 \%)$ and poor $(<50 \%)$ based on the comparison of the TAM in the affected digit, to the contralateral hand or norm of 260 degrees. ${ }^{4}$

Fifty-two injuries were analysed, with all sustained at the workplace. Demographic and perioperative data are presented in Table 1. The demographic characteristics of our patient cohort is similar to previous epidemiological studies on migrant workers in Singapore. ${ }^{5}$ The mean preoperative TAM was 167 \pm 62 degrees. Following surgery and a mean $9.3 \pm 7.0$ weeks of rehabilitation, the mean final TAM improved to $211 \pm 57$ degrees, corresponding to an outcome of "good". Eleven patients $(21 \%)$ achieved "excellent" outcomes, 27 (52\%) achieved "good" outcomes, 9 (17\%) achieved "fair" outcomes and 5 $(10 \%)$ achieved "poor" outcomes. Despite the majority
Table 1. Patient Demographics and Perioperative Data

\begin{tabular}{|c|c|}
\hline Data $(n=52)$ & Measures \\
\hline Mean age $\pm \mathrm{SD}$, years & $32.4 \pm 7.6$ \\
\hline Number of males (\%) & $47(90)$ \\
\hline Number of right-handed individuals (\%) & $50(96)$ \\
\hline Number of dominant hand injuries (\%) & $31(60)$ \\
\hline Number of injuries sustained at workplace (\%) & $52(100)$ \\
\hline Mean preoperative total active motion $\pm \mathrm{SD}$, degrees & $167 \pm 62$ \\
\hline \multicolumn{2}{|l|}{ Digit involved, $n(\%)$} \\
\hline Thumb & $11(21)$ \\
\hline Index finger & $13(25)$ \\
\hline Middle finger & $16(31)$ \\
\hline Ring finger & $6(12)$ \\
\hline Little finger & $6(11)$ \\
\hline \multicolumn{2}{|l|}{ Tissue involved, $n(\%)$} \\
\hline Bone & $27(52)$ \\
\hline Soft tissue & $18(35)$ \\
\hline Tendon & $7(13)$ \\
\hline \multicolumn{2}{|l|}{ Diagnosis classification, $n(\%)$} \\
\hline Open laceration & $14(27)$ \\
\hline Open tuft fracture & $13(25)$ \\
\hline Phalangeal fracture & $13(25)$ \\
\hline Traumatic amputation & $12(23)$ \\
\hline \multicolumn{2}{|l|}{ Type of surgery performed, $n(\%)$} \\
\hline Nail bed repair & $11(21)$ \\
\hline Open reduction and internal fixation & $11(21)$ \\
\hline Tendon repair & $7(14)$ \\
\hline Wound debridement and amputation & $23(44)$ \\
\hline Mean days from admission to surgery $\pm \mathrm{SD}$, days & $1.6 \pm 1.9$ \\
\hline Mean length of hospitalisation $\pm \mathrm{SD}$, days & $2.9 \pm 1.5$ \\
\hline Mean duration of hospitalisation leave $\pm \mathrm{SD}$, days & $12.4 \pm 15.8$ \\
\hline Mean duration of rehabilitation $\pm \mathrm{SD}$, weeks & $9.3 \pm 7.0$ \\
\hline Mean number of therapy sessions attended \pm SD & $6.5 \pm 4.2$ \\
\hline Mean number of therapy sessions per week $\pm \mathrm{SD}$ & $0.9 \pm 0.5$ \\
\hline
\end{tabular}


having excellent or good outcomes, only 10 out of 52 patients $(19 \%)$ returned to work after recovery. Multiple regression analyses found that initial TAM was the only significant predictor for the final TAM $(P<0.0001)$ and for achieving "excellent" or "good" ASSH categories $(P<0.0001)$. There were no good predictors for change in TAM. Number of days from admission to surgery was the only significant predictor for return to work status $(P=0.05)$.

A stable, mobile and sensate fingertip is important to the overall function of the hand. Although fingertip injuries are unlikely to be life-threatening, they can result in permanent impairment ${ }^{6}$ and a detrimental effect on quality of life and independence. ${ }^{7,8}$ This is especially significant amongst workers whose livelihood depends on the use of their hands, and is reflected by the low percentage of patients who returned to work after recovery.

A novel finding in our study is that preoperative TAM is a significant predictor of postoperative TAM and predictor of "good" and "excellent" postoperative outcomes. This information will be useful for preoperative counselling, managing of expectations and setting of postoperative rehabilitation targets.

Early treatment after fingertip injury is one of the prerogatives for successful treatment. Our findings are in concordance, showing that earlier treatment was a significant predictor of return to work status. Apart from early surgical treatment, early return to work may potentially be beneficial. Hung et al studied 28 adult male subjects who suffered from work related finger amputation and reported better rehabilitative outcomes if patients who returned to work early after the treatment, started working with decreased workload which would be gradually increased over time".

In our study, despite satisfactory improvements of TAM, only 10 out of 52 patients $(19 \%)$ returned to work. This contrasts with Cabral et al who conducted a cross-sectional of 35 workers, mostly low-educated, with various hand injuries, and reported an $85.7 \%$ return to work rate, with the majority of injured employed in the same industry. ${ }^{10}$ This may allude to non-medical factors driving the failure to return to work. One such factor may be premature termination, as the cost to replace a worker may be lower than the burden of medical treatment and rehabilitation. This could be compounded by the inability to manage disability at the workplace.

Although we used prospectively collected data, our study is still prone to bias due to its retrospective nature. We also did not have data related to reasons on low return to work status. Further studies exploring reasons for the low return to work rate will help to shed light on the interplay between factors such as the socio-economic status of workers, country of origin, nature of employment and type of contract.

To the authors' knowledge, this is the first study evaluating the functional outcomes and return to work status in migrant construction workers with fingertip injuries following surgery. Migrant workers are an integral part of our society, contributing to Singapore's development and economic growth. Improving care for this population would include reducing workplace injuries, optimising surgical timing, technique and postoperative rehabilitation, as well as addressing the patient's ability to return to functional employment.

\section{Acknowledgement}

We would like to extend our sincere appreciation to the team at Singapore Chief Residency Programme and HealthServe for inspiring this work on migrant workers. We would also like to thank the silent heroes in our community, the migrant workers themselves for contributing to nation building.

\section{REFERENCES}

1. Ministry of Manpower SG. Foreign Workforce Numbers. Available at: http://www.mom.gov.sg/documents-and-publications/ foreign-workforce-numbers. Accessed on 18 January 2018.

2. Ministry of Manpower SG. Workplace Safety and Health Report. Available at: https://www.mom.gov.sg/ /media/mom/documents/ safety-health/reports-stats/wsh-national-statistics/wsh-nationalstats-2017.pdf?la=en. Accessed on 18 January 2018.

3. Adams L, Greene L, Topoozian E. Range of Motion. In: American Society of Hand Therapists, editor. Clinical assessment recommendations. 1992. pp 55-70.

4. Kleinert HE, Verdan C (1983). Report of the committee on tendon injuries (International federation of societies for surgery of the hand). J Hand Surg Am 1983 Sep;8(5 Pt 2):794-8.

5. Carangan M, Tham KY, Seow E. Work-related injury sustained by foreign workers in Singapore. Ann Acad Med Singapore 2004;33:209-13.

6. Courtney TK, Matz S, Webster BS. Disabling occupational injury in the US construction industry, 1996. J Occup Environ Med 2002;44:1161-8. 
7. Covinsky KE, Lindquist K, Dunlop DD, Gill TM, Yelin E. Effect of arthritis in middle age on older-age functioning. J Am Geriatr Soc 2008;56:23-8.

8. Dellhag B, Bjelle A. A five-year followup of hand function and activities of daily living in rheumatoid arthritis patients. Arthritis Care Res 1999;12:33-41.

9. Hung LK, Ho KK, Leung PC. Impairment of hand function and loss of earning capacity after occupational hand injury: prospective cohort study. Hong Kong Med J 1999;5:245-50.

10. Cabral LH, Sampaio RF, Figueiredo IM, Mancini MC. Factors associated with return to work following a hand injury: a qualitative/ quantitative approach. Rev Bras Fisioter 2010;14:149-57.
Wai-Keong $\underline{\text { Mak }},{ }^{1} M B B S$, MRCS, Joseph MY Cheah, ${ }^{1} M B B S$, David TC Chua, ${ }^{1}$ MBBS, FRCSEd (Orth),

Hamid Rahmatullah Bin Abd Razak, ${ }^{1}$ MBBS, FRCSEd (Orth)

${ }^{1}$ SingHealth Duke-NUS Musculoskeletal Sciences Academic Clinical Programme, Singapore

Address for Correspondence: Dr Hamid Rahmatullah Bin Abd Razak, Sengkang General Hospital, 110 Sengkang East Way, Singapore 544886 Email: hamidrazak@gmail.com 